\title{
ОСОБЛИВОСТІ МЕТОДІВ НАВЧАННЯ УКРАЇНСЬКОЇ МОВИ ЯК ІНОЗЕМНОÏ НА ОСНОВНОМУ ЕТАПІ
}

\begin{abstract}
Дирда I. А. Особливості методів навчання української мови як іноземної на основному етапі.

У статті проаналізовано погляди вітчизняних та зарубіжних науковців стосовно тлумачення поняття «метод» та його характеристики у контексті навчання української мови як іноземної. Виокремлено основні методи навчання української мови як іноземної на основному етапі та зазначено особливості таких методів.

Ключові слова: метод, українська мова як іноземна, основний етап навчання, методи навчання.
\end{abstract}

Дырда И. А. Особенности методов обучения украинского языка как иностранного на основном этапе.

В статье были рассмотрены взгляды отечественных и зарубежных ученых относительно понятия «метод» и его характеристики в контексте обучения украинского языка как иностранного. Были выделены основные методы обучения украинского как иностранного на основном этапе и рассмотрены их особенности.

Ключевые слова: метод, украинский язык как иностранный, основной этап обучения, методы обучения.

Dyrda I. A. The peculiarities of methods of studying Ukrainian as a foreign language in the main stage.

The method plays the decisive role in teaching foreign languages. The method of studying language is one of the key categories of the linguistic didactics; this is a way, technique, principles of researching language phenomenon. Ukrainian scientists considers the method of studying as a form of gaining knowledge, skills and abilities in a particular subject; exchange of direct and practical information between a teacher and a student. The methods of studying organize or direct pupils' cognitive activity and stimulate the development of cognitive needs and interests of pupils.

To single out the groups of methods of studying Ukrainian it's sufficient to take into consideration the criteria selecting methods of studying. They are the following: conscious usage of the language to make an accent on cognitive and intellectual skills of students and to make the analysis of induced and perceived statements; social and cultural context of the informative ability to use culturally marked speech units according to communication situation; dealing with specific national behavior models which is characterized to Ukrainian culture; possession of perceptive and reproductive kinds of activity.

In the main stage of studying Ukrainian as a foreign language the following methods can be singled out: direct method, reading method, conscious and comparative method, conscious and practical method, communicative method.

The direct method signifies association of lexical units of a foreign language with

(C) І. А. Дирда, 2016.

$-310-$ 
their meaning not taking a native language into consideration in the educational process. To create the same conditions students have mastering the native language it's necessary to render appropriate language environment on the foreign language lesson. The method of reading is quite efficient because reading leads to increase of speech practice and compensates its lack in the process of studying of a foreign language. Reading a huge amount of texts causes emerging of the language feeling which helps students to overcome the influence of the native language.

Key words: method, Ukrainian as a foreign language, the main stage of studying Ukrainian as a foreign language, methods of studying.

Роль методу у викладанні іноземних мов завжди була вирішальною. Саме на це звертав увагу відомий психолог Б. Бєляєв, який писав: «Оскільки під методом навчання необхідно розуміти сукупність основних методичних принципів, то відмова від певного методу навчання, означає відмову від певних принципів навчання. Хто заперечує необхідність основного методу навчання, той намагається перетворити методику в безпринципну теорію навчання, а відповідну практику цього навчання - у безпринципну діяльність» [3, с. 14].

Метод навчання мови - це один 3 ключових категорій лінгводидактики; це спосіб, прийом, методика дослідження мовних явищ (А. Алексюк, Г. Анісімов, Б. Бєляєв, І. Бім, В. М. Вятютнєв, В. Іваненко, В. Краєвський, М. Ляховицький, Ю. Пасов, Л. Рожило, О. Скорик та ін.)

У розумінні М. Ляховицького, «метод - узагальнена модель реалізації основних компонентів навчального процесу з іноземної мови, в основу якої покладено певну домінуючу ідею розв'язання головного методичного завдання... науково обгрунтована система принципів, що віддзеркалює визначену лінгвістичну й психологічну концепцію» $[7$, с. 71$]$.

На думку українських науковців (А. Алексюк, В. Іваненко, I. Олійник, Л. Рожило, О. Скорик), метод навчання - це форма засвоєння знань, умінь і навичок із певного предмету; це обмін наочною та практичною інформацією між викладачем та студентами. Методи навчання упорядковують і скеровують пізнавальну діяльність учнів, стимулюють розвиток пізнавальних потреб та інтересів учнів.

У сучасній методиці навчання української мови як іноземної апелюють до системи методів в іншомовній аудиторії, де найпоширенішими є класифікації Е. Азімова, А. Арутюнова, І. Бім, А. Щукіна та ін. Зокрема, І. Бім запропонувала розрізняти методи, які 
характеризують діяльність викладача, та ті, що розкривають діяльність студента. До першої групи науковець відносить показ, пояснення, організацію тренувань i застосування. Кожному 3 основних методів відповідають такі другорядні: контроль, корекція та оцінка. Другу складають методи: ознайомлення (чуттєве сприйняття, осмислення, приговорювання; розмірковування (усвідомлення чи пошук певних орієнтирів, розгорнуте міркування); тренування, що залучає практику в штучних умовах; застосування різних видів мовленнєвої діяльності, які співвідносяться 3 практикою в природних умовах як методом пізнання. Супровідними методами при цьому $є$ самоконтроль, самокорекція та самооцінювання.

А. Алексюк здійснює бінарну класифікацію методів за двома істотними ознаками: «характер і рівень пізнавальної самостійності й активності учнів, а також ті джерела, з яких учні набувають знань» $[1$, c. 31$]$.

Окрім класифікації методів за такими ознаками, спостерігаємо спроби створення багатовимірних моделей методів навчання. Так, В. Паламарчук конструює тривимірну систему методів навчання, в основу якої закладено ознаки: перцептивну, гностичну, логічну.

У зв'язку з різними способами взаємодії викладача і студентів О. Біляєв обгрунтував основні методи навчання української мови: усна розповідь або пояснення викладача, бесіда, спостереження студентів над мовою, робота з підручником, метод вправ.

С. Караман, розвиваючи лінгводидактичні ідеї О. Біляєва, звертає увагу на такі аспекти поняття методу навчання:

- ефективність засвоєння мови залежить від правильного розуміння викладачем методів навчання, їх особливостей i класифікаційних структур;

- наявність різних класифікацій у системі методів навчання мови свідчить про науковий пошук, нагромадження й теоретичне узагальнення педагогічного досвіду викладачів, дослідження методів на різних можливих системних рівнях;

- особливість кожного методу створюють в ньому основні прийоми;

- специфіка методів навчання мови зумовлюється закономірностями й принципами ії вивчення, логічною структурою змісту предмета, характером тих знань і вмінь, яких набувають учні, а

○ І. А. Дирда, 2016. 
також системою дидактичних і специфічних прийомів, характерних для вивчення мови;

- важливість поняття спеціального прийому як фактора спеціалізації методу в концепції методів навчання - специфіка вивчення предмета виражена передусім через властиві для нього прийоми, різне співвідношення цих прийомів у системі основних методів;

- при виборі методів навчання мови необхідно керуватися дидактичними і лінгводидактичними принципами, серед них - у першу чергу, дидактичним принципом дотримання єдності змістової і процесуальної сторін у навчанні та специфічним принципом становлення міжпредметних та внутрішньопредметних (внутрішньорівневих і міжрівневих) зв'язків у навчанні мови;

- до основних методів навчання української мови належать: усний виклад учителя, бесіда, спостереження учнів над мовою, робота 3 підручником, метод вправ, а також програмоване навчання, комп'ютеризоване навчання [5, с. 108-112].

У розумінні О. Хорошковської, система методів навчання української мови залучає пізнавальні методи (пояснювальноілюстративний, частково-проблемний, проблемний або пошуковий); метод зіставлення (відкрите/приховане); тренувальні (імітаційний, репродуктивний, оперативний, продуктивно-творчий або комунікативний).

Т. Донченко систематизує методи навчання української мови за напрямками організації навчальної діяльності: 1) організація діяльності, спрямованої на сприймання та осмислення навчального матеріалу (студенти отримують готові узагальнення в процесі викладу навчального матеріалу); 2) організація частково-пошукової діяльності (евристична бесіда); 3) організація самостійного засвоєння знань шляхом вивчення параграфа (розділу) підручника; 4) організація самостійного осмислення учнями навчального матеріалу на основі цілеспрямованих спостережень учнів над мовою i мовленням; 5) організація відтворення учнями отриманих знань (відтворююча бесіда, зв'язне висловлювання студентів на лінгвістичну тему); 6) організація операційної діяльності учнів, спрямованої на застосування отриманих знань i формування навчально-мовних та правописних умінь і навичок; 7) організація процесів сприймання, 
відтворення й продукування 3 боку студентів усного і писемного мовлення.

Задля виокремлення групи методів навчання української мови на основному етапі, доцільно враховувати критерії відбору методів навчання, які були запропоновані М. Вятютнєвим: 1) свідоме володіння мовою, що передбачає акцент на пізнавальних та інтелектуальних здібностях студентів й уможливлює аналіз породжуваних i сприйнятих висловлювань; 2) соціокультурну насиченість матеріалу (уміння застосовувати країнознавчо марковані одиниці мовлення відповідно до комунікативних ситуацій; ознайомлення 3 національно-специфічними моделями поведінки, характерними для української культури; знання історикогеографічного і культурного фону України та вміння їх уживати задля розуміння представників україномовного суспільства); 3 ) одночасне володіння рецептивними та репродуктивними видами діяльності; 4) глобальне володіння мовою, що є можливим за умов оперування студентами такими одиницями, як висловлювання, діалог, текст [4].

У процесі навчання української мови на основному етапі можна викоремити такі методи: прямий, метод читання, усвідомленозіставний, усвідомлено-практичний, комунікативний метод.

Прихильники прямого методу (М. Берліц, Ф. Гуен, О. Єсперсен, Ш. Швейцер) намагалися асоціювати лексичні одиниці іноземної мови безпосередньо з їх значенням, оминаючи рідну мову, у навчальному процесі. Залучаючи рідну мову не можна сформувати у студентів відчуття чужої мови. Для того, щоб створити умови, аналогічні тим, які існують при засвоєнні рідної, необхідно відтворити відповідне мовне середовище на заняттях 3 іноземної мови. Викладання здійснюється лише іноземною мовою, використання безперекладого розкриття значень лексичних одиниць та граматичних явищ 3 використанням різних засобів наочності.

На основному етапі навчання української мови словниковий запас іноземних студентів достатній для того, щоб опанувати нові лексичні одиниці за допомогою пояснення дефініцій нового слова, знаходження синонімів та антонімів.

На думку 3. Бакум, необхідність залучення у процес навчання прямого методу $\epsilon$ очевидною, тому що «більшість викладачів української мови як іноземної не володіють рідною мовою студентів

○ І. А. Дирда, 2016. 
(або мовою-посередником) i, відповідно, не мають змоги використовувати переклад як прийом навчання» [2, с. 231].

У процесі опанування мови на основному етапі головною метою прямого методу, який не передбачає використання рідної мови в процесі вивчення іноземних мов, $\epsilon$ оволодіння навичками іншомовного говоріння та застосування їх в реальному житті, зокрема в професійній сфері.

Метод читання досліджували такі науковці, як О. Бонд, Е. Едді, А. Колман, М. Уест, Р. Файфа, Л. Фоссет, I. Фремон. На думку М. Уеста, читання сприяє збільшенню мовленнєвої практики та значною мірою компенсує ії недолік у процесі навчання іноземної мови. Після прочитання великої кількості текстів 3'являється відчуття мови, що допомагає суб'єкту навчання подолати вплив рідної мови. Науковець наголошує, що норми усного мовлення змінюються швидше за письмові, тому студенту, який бажає навчитися говорити й писати іноземною мовою, необхідно знати, як говорять і пишуть сьогодні, уникаючи застарілої лексики [9].

Теорія усвідомлено-зіставного методу розроблена у працях В. Аракіна, Р. Барсука, І. Бермана, С.Бернштейна, Л. Виготського, П. Гальперіна, Н. Жинкіна, О. Запорожця, О. Леонтьєв, О. Леонтьєва, О. Миролюбова, С. Рубінштейна, І. Рахманова, З. Цвєткової, Л. Щерби.

Основним підгрунтям цього методу навчання були чотири методичні засади: 1) необхідність усвідомленого засвоєння мовних явища та способів їхнього застосування в мовленні; 2) зіставне вивчення мовленнєвих явищ, що передбачало порівняння подібних i контрастних мовленнєвих фактів двох мов 3 метою подолання негативної інтерференції; 3) одночасний розвиток усіх видів мовленнєвої діяльності повинен проходити на основі писемного мовлення, тобто текст і письмові вправи розглядалися як основні джерела формування навичок і вмінь; 4) розмежування активного i пасивного мовного матеріалу, тобто виокремлення навчального матеріалу, призначеного для рецептивного (читання, аудіювання) та репродуктивного (письмо, говоріння) засвоєння [8, с. 16-17].

Аудіолінгвальний метод передбачає автоматичне засвоєння матеріалу, тобто багаторазове прослуховування магнітофонних записів i промовляння мовних структур i мовленнєвих взірців 
(Р. Ладо, Ч. Фріз).

Сутність такого методу можна звести до таких положень: досягнення суб'єктом навчання рівня носія у володінні мовою, що передбачає автоматизацію навичок до такої міри, щоб реакція на висловлювання була миттєвою; уведення лексики не ізольовано, а в контексті: значення лексичної одиниці пояснюється на основі ситуації, що говорить про акцентування на культурологічному аспекті навчання мови; практичне використання мовленнєвих зразків, тоді як надання правил здійснюється після заучування останніх; пріоритет слухання та говоріння над читанням i письмом; задіяння технічних засобів навчання; широке використання трансформаційних і підстановчих вправ, що виконують 3 опорою на модель чи таблицю [6].

В аудіолінгвальному методі використовуються такі основні методичні прийоми: практична спрямованість навчання, принцип усного випередження, принцип роботи за моделями, принцип врахування рідної мови, максимальне використання технічних засобів навчання.

Усвідомлено-практичний метод розробив відомий психолог Б. Бєляєв. Концепцію цього методу вчений подав у вигляді психологічних принципів навчання: мова як засіб комунікації - це цілеспрямована взаємодія між тими, хто вивчає мову; комунікація - це творчий процес, а не оперування заздалегідь набутими вміннями та навичками; основна увага в роботі повинна бути спрямована на розвиток в учнів іншомовного мислення і відчуття мови, що вивчається; навчання чотирьох видів комунікативної діяльності (читання, письма, говоріння та аудіювання) повинне відбуватися одночасно; усвідомлене, творче використання мови в різних комунікативних ситуаціях забезпечить знання системи мови; зміст навчального матеріалу повинен мати вагоме значення для учнів; результативність володіння мовою залежить від наявності автоматизованих мовленнєвих навичок, які мають формуватися в потоці мовлення; навички стають міцнішими за умов усвідомлення суб'єктом навчання дій, що становлять їх підгрунтя; оволодіння іншомовною мовленнєвою діяльністю має відбуватися через відпрацювання навичок, рівномірно розподіляючи вищенаведене відсоткове співвідношення.

В основі навчання української мови як іноземної за усвідомлено(ㄱ.А. Дирда, 2016. 
практичним методом покладено такі методичні принципи: комунікативна спрямованість навчання, або принцип активної комунікації; функціональний підхід до відбору і презентації мовного матеріалу; ситуативно-тематичний принцип організації мовного матеріалу; принцип концентричного розміщення мовного матеріалу.

Значний внесок у розроблення комунікативного методу зробив відомий російський методист Ю. Пасов. Суть цього методу полягає в тому, що навчання мови - це модель природного процесу спілкування цією мовою. У такому випадку комунікативність розглядається не як методичний принцип, а як принцип методологічний, який визначає, 3 одного боку, методичні принципи навчання, а 3 іншого, - вибір загальнонаукових методів пізнання, які використовуються для побудови процесу навчання. У рамках комунікативного методу навчання комунікативність стає пояснювальним принципом побудови процесу навчання. Комунікативний метод грунтується на таких базових загальнодидактичних i методичних принципах: принцип мовленнєво-мисленнєвої активності; принцип індивідуалізації; принцип функціональності; принцип ситуативності; принцип новизни.

\section{Література}

1. Алексюк А. М. Загальні методи навчання у школі / А. М. Алексюк. - [2-е вид., перероб. і доп.]. - К. : Рад. школа, 1981. - 206 с.

2. Бакум 3. П. Українська мова як іноземна: Лінгводидактичні проблеми / 3. П. Бакум // Філологічні студії : Науковий вісник Криворізького державного педагогічного університету : зб. наук. праць. - Вип. 5 / [заг. ред. Ж. В. Колоїз]. Кривий Ріг : Видавничий дім, 2010. - С. 226-232.

3. Біляєв О. М. Лінгводидактика рідної мови / О. М. Біляєв. - К. : Генеза, 2005. $320 \mathrm{c}$.

4. Вятютнев М. Н. Теория учебника русского языка как иностранного : (методические основы) / М. Н. Вятютнев. - М. : Рус. язык, 1984. - 144 с.

5. Караман С. О. Методика навчання української мови в гімназії : [навчальний посібник] / С. О. Караман. - К. : Ленвіт, 2000. -272 с.

6. Ладо Р. Лингвистика поверх границ культур / Р. Ладо // Новое в зарубежной лингвистике. - 1989. - №25. - С. $34-35$.

7. Ляховицкий М. В. Методика преподавания иностранных языков : [учебное пособие] / М. В. Ляховицкий. - М. : Высшая школа, 1981. - 159 с.

8. Щерба Л. В. Преподавание языков в школе / Л. В. Щерба. - М. : Просвещение, 2002. $-210 \mathrm{c}$.

9. West M. Book Title : New Method Readers. Supplementary reader, Standard / M. West. - Edition 3. - New York, London, Longmans, Green and Company, 1957. - P. 3-4.

Стаття надійшла до редакиії 21.10.2015 p. 